\title{
OD LEXINGTON DO TRENTON KILKA REFLEKSJI NA TEMAT ŻYWIOŁU WODY I JEGO WPŁYWU NA DZIAŁANIA WOJSK W PIERWSZYCH LATACH WALKI O AMERYKAŃSKĄ NIEPODLEGŁOŚĆ
}

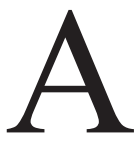
merykańska wojna o niepodległość zaczęła się wiosną 1775 r. od potyczek pod Lexington i Concord (19 kwietnia). Te pierwsze walki przerodziły się w regularną wojnę, którą po ośmiu latach zakończyć miał dopiero pokój w Paryżu podpisany w 1783 r., uznający powstanie Stanów Zjednoczonych Ameryki. Nikt $\mathrm{z}$ amerykańskich przywódców rewolucyjnych nie spodziewał się, że walki będą trwały tak długo. Dopiero po tych wiosennych potyczkach II Kongres Kontynentalny w dniu 14 czerwca 1775 r. powołał Armię Kontynentalną, na którą następnego dnia, dowodzenie powierzył plantatorowi z Południa George’owi Washingtonowi ${ }^{1}$. W dwa dni później miała miejsce jedna w najcięższych bitew, znana jako bitwa o Bunker Hill (Battle of Bunker Hill).

W tym miejscu warto przypomnieć, że koloniści nie mieli armii. W każdej kolonii funkcjonowała jedynie milicja kolonialna, która powoływana była w chwilach zagrożenia ${ }^{2}$. W czasie wojny z Francuzami i Indianami (French and Indian War, 1754-1763) w koloniach funkcjonowały tymczasowe regimenty milicji. Daleko im było do wyćwiczenia i doświadczenia, jakim mogła pochwalić się regularna armia brytyjska.

1 Vide: https://www.mountvernon.org/library/digitalhistory/digital-encyclopedia/article/continental-army/ [dostęp: 16 V 2019 r.].

${ }^{2}$ Każdy stan posiadał jednostki własnej milicji. Zostały one utworzone przez rząd brytyjski w czasie wojny z Francuzami i Indianami, a po niej nie zostały oficjalnie rozwiązane. W ich skład wchodzili mężczyźni w wieku od 16 do 45 lat. Vide: https://www.battlefields.org/learn/articles/fighting-man-continental-army [dostęp: $14 \mathrm{~V} 2019$ r.]. 
Zatem dumnie nazywająca się Armia Kontynentalna (Continental Army) była, przynajmniej początkowo, zbiorem niedoświadczonych ochotników z różnych kolonii, którzy, co najwyżej, mieli doświadczenie w służbie kolonialnej milicji ${ }^{3}$. Na ogół byli to młodzi ludzie pomiędzy 16. a 30. rokiem życia ${ }^{4}$. Przeważali w niej kupcy, rzemieślnicy i farmerzy. Najczęściej byli powoływani do służby na rok ${ }^{5}$ W chwili powstania Armia Kontynentalna składała się z 10 kompanii strzelców (riflemen) z Pensylwanii, Marylandu i Wirginii, zrekrutowanych na okres jednego roku6 ${ }^{6}$. Do tych sił, wywodzących się z kolonii południowych i środkowych, Kongres dołączył rekrutów z kolonii północnych. Było to 22 tys. żołnierzy powołanych w koloniach New Hampshire, Massachusetts, Rhode Island i Connecticut. Wojsko to zostało powołane na wypadek obrony Bostonu i zostało zakwaterowane nieopodal tego kluczowego miasta i portu. Oddziały te liczyły 39 regimentów piechoty, jeden regiment artylerii i jeden wydzielony oddział artylerii. Każdy regiment składał się z ośmiu kompanii - 728 żołnierzy, którymi dowodzili płk (colonel), ppłk (lieutenant colonel) i major. Każda kompania zaś składała się z 90 żołnierzy dowodzonych przez kapitana, jak również pułkowników (lieutenants), chorążych (ensigns) i kornetów (cornets) ${ }^{7}$. Według rozporządzeń, żołnierze mieli otrzymywać po jednym funcie mięsa i chleba, trzy kufle (pints) suszonych warzyw, kufel mleka i kwartę cydru lub piwa ${ }^{8}$. W większości przypadków pozostawało to na papierze, a żołnierze bywali głodni. Nic dziwnego, że Armia potrzebowała nie tylko broni i amunicji, pieniędzy, ekwipunku, mundurów, butów, ale przede wszystkim sprawdzonych dowódców i inżynierów. Ci napływali głównie z Francji.

Armia Kontynentalna musiała walczyć z regularnymi, dobrze wyszkolonymi i wyposażonymi oddziałami brytyjskimi, a także stawiać czoła zmieniającym się porom roku i żywiołom. Jednym z nich była woda. Pierwsza bitwa, jaką stoczyli

\footnotetext{
${ }^{3}$ W czasie wojny o niepodległość w Armii Kontynentalnej służyło łącznie 230 tys. żołnierzy, jednorazowo około 48 tys. Największa liczba żołnierzy biorących udział w walkach wynosiła 13 tys. Vide: https://www.bostonteapartyship.com/facts-continental-army [dostęp: 14 V 2019 r.].

${ }^{4}$ Młodzi chłopcy w wieku 15 lat musieli okazać się zgodą rodziców, aby służyć w Armii Kontynentalnej. Jednak byli i dużo młodsi, jak artylerzysta Jeremiah Levering, który miał 12 lat. Vide: https://www.bostonteapartyship.com/facts-continental-army [dostęp: 16 V 2019 r.].

${ }^{5}$ W 1778 r. Kongres uchwalił także trzyletni czas służby w Armii Kontynentalnej. Służba ponad zakontraktowany czas była płatna. Żołnierz otrzymywał albo dodatkowe pieniądze $(6,23$ \$ na miesiąc), dodatkowe umundurowanie lub nadziały ziemi na zachód od rzeki Ohio. G. Washington służył bez wynagrodzenia, Kongres pokrywał jedynie jego wydatki na prowadzenie wojny. Vide: https://www.battlefields.org/learn/articles/fighting-man-continental-army [dostęp: 14 V 2019 r.]; https://www.u-s-history.com/pages/h3996.html [dostęp: 14 V 2019 r.].

${ }^{6}$ Vide: https://historyofmassachusetts.org/continental-army-revolutionary-war/ [dostęp: $12 \mathrm{~V}$ 2019 r.].

${ }^{7}$ https://historyofmassachusetts.org/continental-army-revolutionary-war/ [dostęp: $12 \mathrm{~V} 2019$ r.]. Kornet to oficer najniższej rangi lekkiej jazdy.

${ }^{8}$ Na podstawie: https://www.bostonteapartyship.com/facts-continental-army [dostęp: $14 \mathrm{~V} 2019$ r.].
} 
żołnierze Armii Kontynentalnej, rozegrała się w dniu 17 czerwca 1775 r. pod Bostonem na wzgórzach zwanych Bunker Hill i Breed's Hill. Mimo że Kongres wyznaczył Washingtona na jej dowódcę, ten nie brał w tej bitwie udziału9 Dowiedział się o niej post factum. Do 21 czerwca przebywał bowiem w Filadelfii, w mieście, w którym rezydowała największa władza rewolucji amerykańskiej, jaką stanowił Kongres Kontynentalny.

Oddziały brytyjskie po przegranych starciach pod Lexington i Concord wycofały się do Bostonu. Ośmieleni zwycięstwem milicjanci zaczęli skupiać się wokół tego miasta. Pod dowództwem Artemasa Warda, w sile około 15 tys. otoczyli miasto, odcinając dostęp od strony lądu i zaczęli klasyczne oblężenie. Nocą z 16 na 17 czerwca niepostrzeżenie przedostali się na półwysep Charleston. Był on od kwietnia opuszczony przez Brytyjczyków. Amerykanie musieli użyć łodzi, gdyż półwysep jest dość znacznie oddalony (około mili, czyli prawie 1,6 km) od lądowej części, na której znajduje się Boston. Tam, pod osłoną nocy, 16 czerwca koloniści ufortyfikowali wzgórza Bunker i Breeds. Jednakże o świcie wartownik z okrętu Lively dostrzegł fortyfikację i powiadomił kapitana. W efekcie, po pierwszych ostrzałach $\mathrm{z}$ wody wojska brytyjskie pod dowództwem gen. Williama Howe zaatakowały i zdobyły wzgórza. Najcięższe walki toczyły się o wzgórze Breeds. Zakończyły się one około godz. 17.00. W dodatku wojska brytyjskie spaliły miasteczko Charles Town znajdujące się w niższej części półwyspu. Brytyjczycy wygrali, ale ich straty były tak duże, że było to pyrrusowe zwycięstwo. Jedna trzecia brytyjskiej armii została wybita, w tym znaczna część oficerów ${ }^{10}$. Siły amerykańskie również ucierpiały, ale znacznie mniej żołnierzy zostało zabitych, natomiast przeważała liczba rannych. Sytuacja pod Bostonem stała się patowa, gdyż ani Brytyjczycy, ani Amerykanie nie mieli przewagi zarówno w ludziach, jak i sprzęcie, aby rozstrzygnąć starcie na swoją korzyść. Obie strony pozostały na swoich pozycjach i trwały tak przez całe lato, jesień i zimę 1775 r., czekając na sprowadzane posiłki. Było to utrudnione $\mathrm{z}$ uwagi na fakt, że brytyjskie okręty wojenne stały wokół Bostonu, a marynarka amerykańska (przypomnę, że do ogłoszenia Deklaracji Niepodległości 4 lipca 1776 r. nie ma Stanów Zjednoczonych Ameryki) w zasadzie nie istniała. Dodatkowo pod koniec roku kalendarzowego kończyły się zaciągi do Armii Kontynentalnej. Żołnierze legalnie poczęli wracać do domów. Pod Bostonem sytuacja stawała się przedziwna: oblegających było coraz mniej w stosunku do obleganych. W tej trudnej sytuacji gen. Washington cały czas był już ze swą armią oblegającą Boston.

\footnotetext{
${ }^{9}$ https://www.battlefields.org/learn/articles/fighting-man-continental-army [dostęp: $26 \mathrm{~V} 2019$ r.].

${ }^{10}$ Szczegółowe dane są następujące: 115 zabitych po stronie amerykańskiej, 305 rannych, 30 pojmanych, z czego 20 zmarło. Razem: 450. Po stronie brytyjskiej: 19 oficerów zabitych, 62 rannych, 207 żołnierzy zabitych i 766 rannych. Razem: 1054. Na podstawie: https://en.wikipedia.org/ wiki/Battle_of_Bunker_Hill [dostęp: 16 V 2019 r.].
} 
Kampania bostońska zakończyła się w marcu 1776 r. ewakuacją sił brytyjskich z Massachusetts. Było to możliwe dopiero wówczas, gdy oddziały amerykańskie uzyskały zdolność do podjęcia działań. Stało się to po zdobyciu na Brytyjczykach ciężkich dział z Fortu Ticonderoga ${ }^{11}$ i przewiezieniu ich pod Boston. W dniu 4 marca 1776 r. Amerykanie pod dowództwem Henry'ego Knoxa rozpoczęli fortyfikację wzgórz Dorchester (Dorchester Heights), na których umieszczono dalekosiężne armaty. $\mathrm{Z}$ nich udało im się ostrzelać nie tylko sam Boston, ale co ważniejsze, brytyjskie okręty zacumowane w porcie. W sukurs wojskom amerykańskim przyszła śnieżyca, która uniemożliwiła wojskom brytyjskim przeprowadzenie ataku i odbicia dział. W efekcie Brytyjczycy dowodzeni przez gen. W. Howe'a zostali zmuszeni do wycofania się z Bostonu w dniu 17 marca. Ten dzień do dziś obchodzony jest jako Evacuation Day. Brytyjczycy skierowali się ku Halifaxowi w Nowej Szkocji. Oddziały lokalnych milicji rozeszły się, zaś Washington poprowadził Armię ku Nowemu Jorkowi z zamiarem ufortyfikowania tego miasta ${ }^{12}$.

W tym miejscu należy przypomnieć, że w czasie oblężenia Bostonu, Kongres podjął nieudaną próbę inwazji na Kanadę w celu pozyskania jej mieszkańców do poparcia amerykańskiej rewolucji ${ }^{13}$. Siłami amerykańskimi dowodzili: gen. major Benedict Arnold i brygadier Richard Montgomery, brytyjskimi zaś gubernator Kanady Guy Carleton i płk Allen Maclean. Siły obu stron były wyrównane i wynosiły po około 1200 żołnierzy ${ }^{14}$.

Bitwa o Quebec, która rozegrała się w ostatni dzień grudnia 1775 r. zakończyła amerykańską inwazję na Kanadę ${ }^{15}$. Wojska amerykańskie uderzyły z dwóch kierunków: z północy od strony rzeki Św. Karola (St. Charles River) atak prowadził B. Arnold, zaś z południa od rzeki Św. Wawrzyńca (St. Lawrence River) dowodził R. Montgomery. Trudnością była nie tylko szerokość rzek, ale również fakt,

${ }^{11}$ Fort Ticonderoga leży na pograniczu z Kanadą. Został wybudowany przez Francuzów w 1755 r. w strategicznym miejscu przewężenia jeziora Champlain. Wówczas nazywał się Fort Carillon. Prawie natychmiast został podstępem zdobyty przez amerykańskich rewolucjonistów zwanych Green Mountain Boys (Chłopcy z Zielonego Wzgórza). Vide: https://pl.wikipedia.org/wiki/Green_ Mountain_Boys [dostęp: 12 V 2019 r.].

12 https://en.wikipedia.org/wiki/Battle_of_Bunker_Hill [dostęp: 16 V 2019 r.].

${ }^{13}$ Oddziały amerykańskie były dowodzone przez brygadiera Montgomery’ego, który prowadził atak na Jezioro Champlain i gen. Benedicta Arnolda maszerującego w kierunku Maine. Ich atak na Quebec podjęty z dwóch stron miasta nie przyniósł powodzenia. Amerykański plan przyłączenia sił francusko-kanadyjskich mieszkańców Kanady do rewolucji, a tym samym kontrolowania drogi wodnej z Wielkiej Brytanii do jeziora Św. Wawrzyńca i wyrzucenia Brytyjczyków z Kanady nie powiódł się. Vide: https://www.britishbattles.com/war-of-the-revolution-1775-to-1783/battle-of-quebec-1775/ [dostęp: 12 V 2019 r.].

${ }^{14}$ Dane na podstawie: https://www.britishbattles.com/war-of-the-revolution-1775-to-1783/battle -of-quebec-1775/ [dostęp: 17 V 2019 r.].

${ }_{15}$ Vide: https://www.britishbattles.com/war-of-the-revolution-1775-to-1783/battle-of-quebec1775/ [dostęp: 12 V 2019 r.]. 
że żołnierze musieli być przetransportowani na ląd łodziami. Niewątpliwie atakującym Amerykanom utrudniła zadanie burza śnieżna, która się wtedy rozszalała ${ }^{16}$. Dodatkową trudność atakującym sprawiła słaba widoczność, przede wszystkim wskutek śnieżnej zamieci, a ponadto bitwa toczyła się nocą, co także miało wpływ na ograniczoną widoczności. Brytyjczycy stracili 20 żołnierzy, Amerykanie zaś aż około 500. Już te dane wskazują, że wojska amerykańskie nie potrafiły walczyć w zimowych, kanadyjskich warunkach. W efekcie Amerykanie wycofali się z Kanady i nie ponawiali prób wciągnięcia jej w wir wojny o niepodległość.

Wymienione trzy bitwy, a więc Lexington i Concord (kwiecień 1775), a następnie Bunker Hill (czerwiec 1775) i Quebec (grudzień 1775) zajmują trzy pierwsze pozycje na liście 10 najważniejszych bitew wojny o niepodległość Stanów Zjednoczonych ${ }^{17}$. Czwartą pozycję na tej liście zajmuje bitwa o Charleston z czerwca 1776 r., a piątą pod Trenton $\mathrm{z}$ grudnia tego roku.

Zajmijmy się jednak najpierw bitwą o Long Island, czyli o Długą Wyspę, która miała miejsce 27 sierpnia 1776 r. Chodziło w niej bowiem o utrzymanie kolejnego dużego miasta-portu, jakim był Nowy Jork. Brytyjski gen. dywizji W. Howe poprowadził swe wojska wraz z oddziałami heskimi przeciwko Armii Kontynentalnej dowodzonej przez gen. G. Washingtona. Miał dwukrotną przewagę liczebną, gdyż siłę wojsk brytyjskich ocenia się na 20 tys., zaś amerykańskich na 10 tys. żołnierzy. Broń to głównie muszkiety i bagnety, co stanowiło wówczas podstawę uzbrojenia armii. Obie strony były wspierane przez artylerię ${ }^{18}$. Bitwę tę rozpoczęli i wygrali Brytyjczycy. Efektem było wycofanie się wojsk amerykańskich z Brooklynu i ewakuacja Nowego Jorku.

Gen. W. Howe nieco przechytrzył G. Washingtona, który oczekiwał, że po opuszczeniu Bostonu, Brytyjczycy skierują swój atak na Nowy Jork. Dlatego też armia gen. G. Washingtona zajęła strategiczne pozycje na południe od Nowego Jorku. Tymczasem gen. W. Howe zamiast na południe z Bostonu, udał się najpierw na północ do Halifaxu w Nowej Szkocji, a dopiero latem 1776 r. przystąpił do ataku na Nowy Jork. Brytyjska flota dotarła do rzeki Hudson w dniu 29 czerwca. W. Howe wylądował zaś na Staten Island kilka dni później, bo 3 lipca. Nazajutrz Kongres ogłosił przełomowy dokument dla wojny o niepodległość, jakim była Deklaracja Niepodległości. Dla Brytyjczyków liczyły się jednak napływające posiłki, a nie uzurpatorski, jak określali, dokument rewolucjonistów. Dla Amerykanów

16 Vide: https://www.history.com/topics/american-revolution/battle-of-quebec-1775 [dostęp: 17 V 2019 r.].

${ }^{17}$ Klasyfikacji tej dokonali amerykańscy historycy na łamach czasopisma naukowego „Journal of the American Revolution”. Vide: https://allthingsliberty.com/2013/09/top-10-battles-revolutionary-war/ [dostęp: 18 V 2019 r.].

${ }^{18} \mathrm{Na}$ podstawie: https://www.britishbattles.com/war-of-the-revolution-1775-to-1783/battle-of-long-island/ [dostęp: 18 V 2019 r.]. 
zaś stanowił on przełomowy moment rewolucji i początek istnienia własnego, nowo utworzonego państwa. Amerykanie zaś zdążyli zbudować na Manhattanie i Long Island (Długiej Wyspie) baterie, które uniemożliwiały brytyjskiej flocie przebicie się przez Nowy Jork. G. Washington ponadto rozlokował większość swych żołnierzy (10 tys. z 18 tys., jakimi dowodził) w fortyfikacjach znajdujących się na Wzgórzach Brooklynu (Brooklyn Heights), aby bronić podejścia do Manhattanu zarówno od strony lądu, jak i morza. Siłami tymi dowodził gen. dywizji (major general) Israel Putnam. Część sił amerykańskich miała bronić ufortyfikowanego obszaru wzdłuż wybrzeża, ale główne siły znajdowały się wokół wzniesienia w głębi lądu.

W dniu 22 sierpnia 1776 r. siły brytyjskie wylądowały na Długiej Wyspie na południe od amerykańskich fortyfikacji. Po czterech dniach, 26 sierpnia, główna część wojsk brytyjskich wymaszerowała na północny wschód, ale poniżej linii obsadzonych na wzgórzu przez Amerykanów. W dodatku Brytyjczycy dostrzegli lukę w linii obrony, gdyż najbardziej wysunięta na północ z trzech dróg na wzgórzu nie była broniona. Tam W. Howe przypuścił atak, a z drugiej strony zaatakowały wspomagające go oddziały heskie ${ }^{19}$. Amerykanie nie utrzymali pozycji i wycofali się. Walki trwały jednak nadal. G. Washington 28 sierpnia sprowadził posiłki z Nowego Jorku, ale nie docenił siły Royal Navy. Ponadto zaczął padać deszcz, więc G. Washington kazał swoim oddziałom zaatakować Brytyjczyków w nocy. Deszcz jednak nie ustawał. Następnego dnia wycofał się więc z Brooklynu. Gen. W. Howe umożliwił Amerykanom bezpieczny odwrót. Tak samo zachował się podczas wycofywania sił amerykańskich z Nowego Jorku. Po prostu nie podejmował działań ofensywnych. Nowsze badania dowodzą jednak, że bezczynność Brytyjczyków podyktowana była panującą mgłą. Amerykanie ewakuowali się pod jej osłoną, a brytyjscy dowódcy po prostu tego nie zauważyli.

G. Washington wycofał się nad rzekę Delaware, gdzie jego wojska zostały na zimę. Amerykanie ponieśli ogromne straty. Szacuje się, że stracili około 2 tys. zabitych, rannych i wziętych do niewoli, zaś Anglicy szacowali straty na 400 żołnierzy ${ }^{20}$. Najważniejszym zadaniem, które stanęło przed gen. G. Washingtonem było odbudowanie stanu liczebnego armii, a przede wszystkim podniesienie morale żołnierzy.

Można powiedzieć, że kolejna bitwa, jaką stoczyły wojska G. Washingtona nieco te morale odbudowała. Była to bitwa o Wzgórza Harlemu (Harlem Heights), która rozegrała się 16 września 1776 r. Brytyjczycy dysponowali potężną siłą swej

${ }^{19}$ Bitwa o Long Island (Długa Wyspa) zwana jest także bitwą o Brooklyn, a także bitwą o Wzgórza Brooklynu (Brooklyn Heights). Vide: https://www.history.com/topics/american-revolution/ battle-of-long-island [dostęp: $18 \mathrm{~V} 2019$ r.].

${ }^{20}$ https://www.britishbattles.com/war-of-the-revolution-1775-to-1783/battle-of-long-island/ [dostęp: 18 V 2019 r.]. 
floty, która poprzedniego dnia (15 września) dopłynęła do wybrzeży Nowego Jorku i przy użyciu wielkiej ilości szerokodennych łodzi wysadziła swych żołnierzy na ląd. Bitwa, a raczej potyczka, nie została jednoznacznie rozstrzygnięta, ale była walką o godność, gdyż brytyjskie oddziały lekkiej piechoty grały swym oddziałom melodię, którą trąbi się w czasie polowania na lisy ${ }^{21}$. Brytyjczycy potraktowali żołnierzy amerykańskich jak uciekającą zwierzynę, do której się strzela. Ta jawna pogarda wywołała zamierzony efekt, gdyż Amerykanie początkowo bardzo się denerwowali, ale stopniowo zaczęli „zbierać się w sobie”. Prowadzili walkę przez godzinę, albowiem G. Washington, widząc nadchodzące brytyjskie posiłki, nakazał wycofanie się. Wcześniej jednak, sam będąc wzburzony lekceważącym zachowaniem wroga, rozkazał podjęcie ataku, w wyniku którego śmierć poniósł dowodzący nim oficer. Był nim Thomas Knowlton, którego pomnik stoi do dziś w Hartford, w stanie Connecticut. O ironio, to właśnie dźwięki tej szyderczej melodii dodały bojowego ducha Amerykanom.

Droga do zwycięstwa była jednak daleka. Prowadziła przez klęski, jak chociażby w bitwie o Białą Równinę (White Plains), która rozegrała się 28 października 1776 r. Mimo że siły obu stron były raczej wyrównane, to zwycięsko wyszli z niej Brytyjczycy dowodzeni przez gen. porucznika (lieutenant general) W. Howe'a ${ }^{22}$. Ta przegrana zepchnęła Amerykanów do rzeki Delaware. Brytyjczycy zdobyli również Fort Washington w dniu 16 listopada 1776 r. leżący na północnym krańcu Manhattanu w pobliżu Wzgórz Harlemu. Gen. Howe wezwał załogę Fortu do poddania się. Amerykanie odrzucili tę propozycję, w wyniku czego wojska brytyjskie, wzmocnione heskimi posiłkami, rozpoczęły działania. Brytyjskie baterie umieszczone po drugiej stronie rzeki Harlem i fregata Pearl rozpoczęły ostrzał. Przewaga wojsk brytyjskich przypieczętowała losy fortu ${ }^{23}$. Brytyjczycy, których siły liczyły, wraz z heskimi najemnikami około 4 tys. stracili w walce ponad 300 ludzi, głównie Hesów. Natomiast Amerykanie, którzy mieli o połowę mniej żołnierzy, stracili również około 300 żołnierzy, wliczając $\mathrm{w}$ to zabitych, rannych i popadłych $\mathrm{w}$ niewolę ${ }^{24}$. Fort przeszedł $\mathrm{w}$ ręce wroga, a G. Washington z Armią Kontynentalną wycofali się nad rzekę Delaware.

${ }^{21}$ Była to melodia „Gone away”. Vide: https://www.britishbattles.com/war-of-the-revolution-1775-to-1783/battle-of-harlem-heights/ [dostęp: 18 V 2019 r.].

${ }^{22}$ Żołnierzy brytyjskich wraz z heskimi było 13 tys., amerykańskich 14,5 tys. Faktyczny udział w bitwie brało jednak około 4 tys. po każdej stronie. Vide: https://www.britishbattles.com/war-of-the-revolution-1775-to-1783/battle-of-white-plains/ [dostęp: 18 V 2019 r.].

${ }^{23} \mathrm{~W}$ bitwie tej wzięło udział 8 tys. żołnierzy brytyjskich i heskich przeciwko około 2,9 tys. amerykańskich, https://www.britishbattles.com/war-of-the-revolution-1775-to-1783/battle-of-fort-washington/ [dostęp: 18 V 2019 r.].

${ }^{24}$ https://pl.wikipedia.org/wiki/Bitwa_pod_White_Plains [dostęp: 26 V 2019 r.]. Vide sc: https://www.britishbattles.com/war-of-the-revolution-1775-to-1783/battle-of-white-plains/ [dostęp: 26 V 2019 r.]. 
To właśnie przez tę rzekę głównodowodzący sił amerykańskich poprowadził atak na wojska brytyjskie. Przeprawa miała miejsce 25 grudnia 1776 r. Trwała od zachodu słońca do trzeciej nad ranem. Atak przez skutą lodem i pokrytą krą rzeką Delaware był całkowitym zaskoczeniem dla wojsk brytyjskich. Termin również nie został przypadkowo wybrany przez G. Washingtona, gdyż był to pierwszy dzień świąt Bożego Narodzenia.

Obraz przedstawiający G. Washingtona przeprawiającego się na dziobie łodzi przez pokrytą krami rzekę Delaware jest nieodłącznie kojarzony z pierwszą zimową kampanią wojny o niepodległość. Jest symbolem odwagi i hartu ducha Amerykanów. Stał się jednym z najważniejszych obrazów historycznych w kulturze Stanów Zjednoczonych. Tymczasem obraz został namalowany dopiero w $1851 \mathrm{r}$. Jego autorem jest Emanuel Leutze, niemiecki malarz, który nie był nigdy w Stanach Zjednoczonych. Widoczna na obrazie rzeka to nie Delaware, a Ren. Powiewająca na obrazie flaga jest owszem flagą rewolucji amerykańskiej, ale późniejszą, ustanowioną przez Kongres w czerwcu 1777 r. Na obrazie powinna powiewać tzw. Wielka Flaga Unii (Grand Union Flag) z brytyjskim krzyżem w lewej górnej części, widnieje zaś tam koło składające się z 13 gwiazd symbolizujących unię 13 stanów. Dumnie stojący na dziobie gen. G. Washington ukazany został w patriotycznej, heroicznej postawie, która nie ma nic wspólnego z zasadami bezpieczeństwa podczas przeprawy, nie wspominając już o możliwości stania się łatwym celem dla wroga. W rzeczywistości siedział on w środku łodzi wśród innych żołnierzy. Przeprawa była przeprowadzana pod osłoną nocy i zachmurzonego nieba, a na obrazie świeci słońce na tle bezchmurnego nieba. W dodatku w nocy rozpętała się burza śnieżna. Przedstawione postaci żołnierzy mają nieskazitelne mundury, podczas gdy pod koniec kampanii 1776 r. mundury były poszarpane i brudne. Łodzie używane do przeprawy były znacznie szersze i dłuższe. Same zaś twarze i postaci ukazanych żołnierzy były dobierane przez malarza w dość ciekawy sposób. Otóż według opisu przyjaciela malarza, amerykańskiego pejzażysty Johna Worthingtona, Leutze

[...] miał ogromne trudności ze znalezieniem amerykańskich typów dla głów i sylwetek, gdyż wszyscy niemieccy modele byli albo zbyt niscy, albo zbyt krępi. Chwytał więc każdego Amerykanina, jaki pojawił się w pobliżu i nakłaniał go do pozowania. [...] szczupły mężczyzna o chorowitym wyglądzie, który w istocie przez całe życie był pół inwalidą, namalowany z bandażem wokół głowy, został przedstawiony jako ranny, umieszczony w łodzi wraz z innymi, podczas gdy ja [Worthington - J.D.] służyłem malarzowi dwukrotnie: raz jako sternik z wiosłem w dłoni i ponownie jako sam Waszyngton ${ }^{25}$.

${ }^{25}$ J. Worthington, The Autobiography of Warthington Whittredge, cyt. za: H. Rachlin, Skandale, wandale i niezwykłe opowieści o wielkich dziełach sztuki, Poznań 2010, s. 154. 
Ponadto G. Washington powinien być na obrazie młodszy. Miał wówczas 44 lata.

Wracając jednak do przebiegu bitwy, nad ranem tuż po przeprawie doszło do starcia. Atak w tym miejscu nie był przypadkowy. Dzięki schwytaniu Johna Honeymana, uważanego za lojalistę, okazało się, że brytyjskie oddziały powróciły na leża zimowe do Nowego Jorku i na Staten Island. Kilka pozycji w New Jersey było obsadzonych przez heskich najemników. Informacje te zostały wykorzystane przez G. Washingtona. Na tym się jednak nie skończyło. Informator powrócił do angielskich oddziałów i przekazał im, że Amerykanie są całkowicie zdemoralizowani, wyczerpani i niezdolni do prowadzenia jakiejkolwiek walki. Najprawdopodobniej był to jednak amerykański szpieg w służbie wojsk brytyjskich ${ }^{26}$.

Tę sytuację wykorzystał G. Washington. Po pierwsze, zdecydował się na niespodziewany atak, a po drugie, jeszcze w grudniu mógł liczyć na konkretne siły w swej armii, albowiem z dniem 31 grudnia wielu żołnierzom kończył się czas służby. Niespodziewanym sojusznikiem G. Washingtona okazała się ignorancja dowódcy brytyjskiego garnizonu, który został ostrzeżony przez sprzyjającego Brytyjczykom farmera $\mathrm{z}$ hrabstwa Bucks, ale zignorował te wiadomości ${ }^{27}$. Prawdopodobnie wiadomość o planowanym ataku na Trenton przekazał jednak szpieg w sztabie gen. G. Washingtona. Nie wiadomo dokładnie, kto mógł nim być, ale raczej wyklucza się farmera, zważywszy zwłaszcza na okoliczności pory roku. Mogli takie wieści przekazać również dezerterzy z Armii Kontynentalnej ${ }^{28}$. Tym niemniej brytyjski dowódca garnizonu James Grant nie uwierzył w te informacje, aczkolwiek przekazał je gen. Leslie i płk. Von Donop, którzy przekazali je jeszcze dalej, do płk. Johanna Ralla z Trenton. Nikt z nich nie uwierzył w przekazane informacje, a J. Rall odgrażał się, że w razie czego żołnierze hescy pójdą na Amerykanów $\mathrm{z}$ bagnetami ${ }^{29}$. Informacje uznano więc za fałszywy alarm, a nasilająca się burza śnieżna potwierdzała jeszcze te przypuszczenia. Trenton było tak trudno dostępne, że żołnierze hescy nie wystawili straży od południowej strony miasta, uważając, że są bezpieczni. Bitwa pod Trenton była więc całkowitym zaskoczeniem

${ }^{26}$ John Honeyman był wiarygodny dla obu stron. W zasadzie był to tzw. podwójny agent z przewagą działań jednak dla strony amerykańskiej. Vide: https://en.wikipedia.org/wiki/Battle_of_Trenton [dostęp: $23 \mathrm{~V} 2019$ r.].

${ }^{27}$ I. Rusinowa, Saratoga-Yorktown 1777-1781. Z dziejów wojny amerykańsko-angielskiej, Warszawa 1984, s. 74-78.

${ }^{28} \mathrm{https} / / /$ www.mountvernon.org/george-washington/the-revolutionary-war/the-trenton-princeton-campaign/10-facts-about-washingtons-crossing-of-the-delaware-river/ [dostęp: $22 \mathrm{~V} 2019 \mathrm{r}$.]

${ }^{29}$ Było to oznaką brawury i lekceważenia przeciwnika, gdyż dzień wcześniej J. Rall miał spotkanie z dwoma amerykańskimi dezerterami, którzy przekroczyli rzekę i powiedzieli mu, że armia amerykańska jest gotowa do jej sforsowania. Pozostaje do dziś niewyjaśnioną zagadką, dlaczego J. Rall nie wzmocnił swych sił. Vide: https://www.mountvernon.org/george-washington/the-revolutionary-war/the-trenton-princeton-campaign/10-facts-about-washingtons-crossing-of-the-delaware-river/ [dostęp: 22 V 2019 r.]. 
dla Brytyjczyków i służących w ich wojsku Hesów. Zarówno termin, jak i wydawało się niemożliwa do przepłynięcia o tej porze roku rzeka, okazały się atutem G. Washingtona.

Garnizon heski stacjonujący w Trenton, w stanie New Jersey, liczył około 1400 żołnierzy ${ }^{30}$. Armia G. Washingtona, której udało się przeprawić, była w sile 2400 żołnierzy ${ }^{31}$. Plan ataku przewidywał przeprawienie się przez rzekę w trzech miejscach, tak aby Trenton zaatakować od północy i od południa. Udało się to tylko w jednym z wyznaczonych miejsc ${ }^{32}$. Przeprawą dowodził płk Henry Knox. Jak wspomniałam, do przeprawy wykorzystano szerokie płaskodenne łodzie, znane jako łodzie Durham, na ogół liczące od 40 do 60 stóp długości, o wzmocnionych burtach, które poradziły sobie z pływającymi bryłami lodu. Natomiast armaty i konie były przeprawiane na dużych płaskodennych łodziach/barkach przeznaczonych do transportu ciężkich ładunków. Prawdopodobnie były one przymocowane do lin, które umieszczono po obu stronach rzeki. Były swego rodzaju promem. Można powiedzieć, że G. Washingtonowi sprzyjało szczęście, gdyż łodziami sterowali doświadczeni wodniacy (watermen) z Nowej Anglii i Filadelfii. To oni umiejętnie przeprowadzili łodzie przez tak trudną do przebycia zimową rzekę. Przeprawa była coraz trudniejsza, gdyż pogarszały się warunki pogodowe. Nadeszła silna burza, lodowaty deszcz, śnieg i porywisty wiatr. Na rzece była dużej wielkości kra, która mogła rozbić załadowane ludźmi czy sprzętem łodzie. Burza śnieżna nasiliła się o 11 wieczorem³ ${ }^{33}$. Przeprawa zakończyła się dopiero o 3 nad ranem. Żołnierze G. Washingtona byli zmęczeni, głodni, nie mieli ciepłych ubrań. Nie dość, że pokonać musieli wiele kilometrów nocą i w śniegu, aby dotrzeć na miejsce przeprawy, to jeszcze po wylądowaniu okazało się, że do Trenton trzeba było pokonać ponad 9 kilometrową drogę, w dodatku śliską od lodu i śniegu. Temperatura wynosiła zaledwie 2-3 stopnie (29-33 stopnie Fahrenheita). Gen. Washington rozważał nawet odstąpienie od ataku. Ciężki sprzęt, na który składało się 18 armat, a zwłaszcza 6 funtowe działa ważące prawie $800 \mathrm{~kg}$ (1750 funtów), sprawiał najwięcej trudności. Wojsko amerykańskie w tych ekstremalnie trudnych warunkach maszerowało od przeprawy do Trenton jeszcze przez cztery godziny.

${ }^{30} \mathrm{~W}$ większości informacji spotkałam się jednak, że liczbę heskich żołnierzy szacuje się na nieco większą, bo wynoszącą ponad 1,5 tys. Vide: https://www.landofthebrave.info/battle-of-trenton.htm [dostęp: 23 V 2019 r.].

${ }^{31}$ Siły G. Washingtona liczyły 2,4 tys. ludzi. Oddziałami piechoty dowodzili generałowie (major generals) Nathanael Greene i John Sullivan, artylerią dowodził brygadier generalny (brigadier general) Henry Knox. Vide: https://www.history.com/topics/american-revolution/battles-of-trenton-and-princeton [dostęp: $23 \mathrm{~V} 2019$ r.].

${ }^{32} \mathrm{https} / / /$ www.mountvernon.org/george-washington/the-revolutionary-war/the-trenton-princeton-campaign/10-facts-about-washingtons-crossing-of-the-delaware-river/ [dostęp: $22 \mathrm{~V} 2019 \mathrm{r}$.].

${ }^{33} \mathrm{https} / /$ www.mountvernon.org/george-washington/the-revolutionary-war/the-trenton-princeton-campaign/10-facts-about-washingtons-crossing-of-the-delaware-river/ [dostęp: $22 \mathrm{~V} 2019 \mathrm{r}$.] 
Bitwa rozegrała się około 8 rano 26 grudnia 1776 r. Mimo wyczerpania wojska, głodu, zimna i fatalnych warunków pogodowych zwyciężyli Amerykanie. Nie ponieśli przy tym prawie żadnych strat, gdyż stracili dwóch żołnierzy (jeszcze w czasie marszu) i dwóch rannych. Podaje się, że był to jeden oficer i jeden szeregowiec $^{34}$. Straty heskie to 22 zabitych, 92 rannych, 918 wziętych do niewoli i 400, którzy uciekli ${ }^{35}$. Oddział wojsk amerykańskich był podzielony na dwie kolumny. Jedna była dowodzona przez gen. Nathanaela Grene’a, która atakowała od strony rzeki. Z kolei drugą dowodził gen. John Sullivan. Ta miała zaatakować miasto od zachodu. W ataku na Trenton brał udział także Alexander Hamilton, który prowadził ostrzał artyleryjski.

Walki zakończyły się o 9.30 rano. Choć trwały krótko, to były bardzo ciężkie zarówno dla strony amerykańskiej, jak i brytyjskiej. Żołnierze amerykańscy byli niesamowicie wymęczeni zimnem, przeprawą przez lodowatą rzekę i długim marszem w zawiei śnieżnej, brytyjsko-hescy zaś obchodzeniem świąt Bożego Narodzenia, przerwanym nagłym, niespodziewanym atakiem Amerykanów.

Następstwa zwycięstwa pod Trenton były bardzo istotne dla utwierdzenia Amerykanów w wierze, że są w stanie pokonać Brytyjczyków. Przekonali się, że aby wygrać, nie trzeba ponosić wielkich strat własnych. Dowiedli, że są w stanie pokonać regularną armię, a ponadto doborowe oddziały, jakimi byli Hesi w służbie brytyjskiej. Bitwa dała także realne materialne zyski, jakimi było zdobycie sześciu dział, 40 koni i dużo zapasów broni, oraz zapasy żywności. Rola G. Washingtona jako głównodowodzącego Armią Kontynentalną potwierdziła się i usnęła w cień jego poprzednie klęski. Zwycięstwo to podniosło ducha bojowego żołnierzy. Wielu z dotychczas walczących właśnie po Trenton przedłużyło kontrakty na dalszą służbę. To wszystko umożliwiło G. Washingtonowi wykonanie kolejnego śmiałego posunięcia, jakim był atak na Princeton w dniu 3 stycznia 1777 r.

Jolanta A. Daszyńska

\section{FROM LEXINGTON TO TRENTON. SOME REFLECTIONS ON THE ELEMENT OF WATER AND IT'S INFLUENCE ON MILITARY OPERATIONS DURING THE FIRTS YEARS OF AMERICAN WAR OF INDEPENDENCE}

Summary: The battle of Lexington, 1775 started the American War of Independence. The Continental Army was raised by the Second Continental Congress on June 14, 1775 and two days after it fought in the first battle, known as the battle of Bunker Hill (June 17, 1775). George Washington was appointed as the Commander-in-Chief. He did not took part in it, staying already at Philadelphia.

34 Vide: https://pl.wikipedia.org/wiki/Bitwa_pod_Trenton [dostęp: 27 V 2019 r.].

35 https://www.history.com/topics/american-revolution/battles-of-trenton-and-princeton; cf.: https://www.landofthebrave.info/battle-of-trenton.htm [dostęp: 23 V 2019 r.]. 
The British Pyrrhic victory caused the break in the fights till the Spring of 1776. In March because of a strong flury the British troops could not to attack, and as a result they left Boston on March 17. This day is celebrated as an Evacuation Day.

While General Washington, with the American Army, was blockading the British garison in Boston, the other troops led the attack to invade Canada. They attacked from two maine rivers: The St. Lawrence River and St. Charles River. But the wide and ice covered rivers caused the big problem with transportation of soldiers. This time a snowstorm stopped the American attack, and they withdrew from Canada.

The disastrous defeat of the Americans in the battle of Long Island on August 27, 1776 was the first battle after the Proclamation of Independence which led to the loss of New York and retreat to the Delaware River. Heavy rain was a non-attack factor.

Among the presented battles, some of them were victories, but some were the defeats of the American soldiers. The nature and the elements of cold, frost, rains, snowstorms, icy roads and ice-covered rivers were not the ally for attacking troops. But sometimes, such an extreme weather conditions led to success, as it was during the battle of Trenton, after Washington's famous crossing the Delaware River. The image on it is the best known battle picture in the world.

Keywords: battles for independence, winter campaign, Lexington, Trenton, Long Island. 